\title{
A Study Of Labour Turnover And Organisational Productivity In The Cable Industry of Nigeria Manufacturing Sector
}

\author{
Babalola Oluwayemi Oginni \\ Department of Economics and Business Administration, \\ Redeemer's University, Ogun State, Nigeria. \\ Samuel Olufemi Omoyele \\ Department of Economics and Business Administration, \\ Redeemer's University, Ogun State, Nigeria.
}

\begin{abstract}
The paper focused on the role of labour turnover in organisational productivity in the manufacturing sector with reference to cable industry in Lagos, Nigeria with a view to identifying causes of labour turnover and factors in productivity level; elements of organisational policies; and assess challenges confronting the variables. The study provides a framework to explain factors responsible for labour turnover with its implications on organisational productivity as it was found in the cable manufacturing sector of Nigerian economy which has not been previously investigated by scholars. A survey design was adopted, 5 cable organisations were purposively chosen through a preliminary survey of the cable organisations in the three senatorial districts of Lagos State. A sample of 420 employees was chosen from 650 employees representing $65 \%$ response rate. The administered questionnaire was designed in line 5 Likert rating scales. It was found that employees' decision to leave and join another organisation is a constant phenomenon in the world of work which is contingent on many variables such as work design, emotional trauma, location and organisational politics emanating from organisational policies etc. and the result also showed that there is a significant relationship between labour turnover and productivity level of organisation at 0.05 level of sig. It showed that work factors, environmental factors, personal factors as well as organisational policies factors are the basic components of labour turnover with degree of influence on the organisational productivity.
\end{abstract}

Key Words: Labour turnover, productivity, environmental factor, work and personal factors, job enlargement and enrichment

\section{INTRODUCTION}

The increasing complexity of business at all facets of its activities in various industries in Nigeria made a research into labour turnover an indispensable part of organisational development towards achieving its primary objectives i.e to survive, to grow and make profit and for such dream to be actualised, productivity should not be relegated but given highest consideration (Akinwusi, 1989). Thus, the survival of any organisation largely depends on their level of productivity which is believed to be the life-wire of all organisations without exception (Oginni, 2011). It is therefore imperative to understand what should be done to maintain and increase productivity which remains the greatest concern of every organisation and for these wishes to be realised, there is need for something inform of investment from which movement out of the organisation could be reduced to maintain relative stability in the workforce. This is simply because organisations are expected to have certain degree of labour turnover without which the organisation would stagnate or to say that an organisation where nobody leaves nor enters is said to be non-existence (Obisi, 1996). Although in the views of many, labour turnover 
is like a double-edged sword or mixed blessing (Graham, 1990. Obisi, 1996, Banjoko, 2000, Fajana, 2011) i.e if it is through a normal process of replacing old employees, it is acceptable but where it is as a result of non-performance on the part of the worker or organisation, then it is not too good as this would affect the career growth of workers as well as their commitment. However, many factors contributed to the increase and decrease in productivity (Akindele, 1999), but the major concern here was the human resources factor with a projection that a judicious use of this factor would help to maintain, motivate, and reduce whatever might be the effect on the organisation and subsequently meet both primary and secondary objectives of the organisation thus strengthening the rationale behind the essence of joining, identifying and remaining with organisation.

\section{Statement of Problem}

All the activities of any organisation are initiated and determined by the people who make up that organisational plants, offices, computers and automated equipments for meaningful results i.e all these elements found in the modern organisations are unproductive without human efforts through effective interaction. The implication of this on organisational activities is to ensure effective utilisation of this human resources factor by aligning organisational objectives (profit, growth and survival) and employees' objectives (career, job security and societal status) thus bringing about a sort of investment on the human resources factor in order to maintain a relatively stable workforce. However, business organisation in Nigeria are undergoing distress in response to global economic and financial meltdown as well as governmental policies developed in furtherance of economic recovery thus forcing many organisations to adopt different strategies (reorganisation, restructuring, rationalisation, downsizing, rightsizing, retrenchment, merger and acquisition) as a way to cope with the situation and at the end serving as obstacles to also make available welfare packages and work environment that might induce workers to show the desire to stay on the job. In the same vein, it is equally this economic distress that made workers to constantly seek alternative job in order to meet ends meet. Sequel to all these is instability in the workforce which has the propensity to disrupt production, services and in all organization productivity. Hence, the need to investigate the role of labour turnover in organisational productivity level in order to ensure operation on-going concern since the productivity of an organisation depends on the skills or expertise of its workforce with relatively stable personnel or workforce.

\section{Objective of the study}

The rationale behind the study was quite explicit through the focus of the paper i.e the roles of labour turnover in organisational productivity, however within this broad objective were other specific objectives that provided platform for actualisation of the overall objective to include;

1. identify causes of labour turnover and factors in productivity level (increase and decrease)

2. examine intrinsic and extrinsic elements of organisational policies vis-a-vis provision of facilities made available on labour turnover and productivity.

3. investigate the role of labour turnover in the organisational productivity with respect to the cable industry of the manufacturing sector.

4. assess various challenges confronting labour turnover and organisational productivity.

\section{Research Questions}

To effectively evaluate and understand the direction and issue into which research is being carried out, the following questions were raised;

1. What are the factors responsible for labour turnover?

2. What are the factors responsible for increase and decrease in productivity level? 
3. Of what significant are the intrinsic and extrinsic elements of organisational policies and facilities on labour turnover and productivity?

4. What is the relationship between roles of labour turnover in the organisational productivity with respect to the cable industry of the manufacturing sector?

5. What are the challenges encountered in the labour turnover and productivity?

\section{Scope of the study}

The entire work of this research was concentrated on employees of the cable industry in Lagos ranging from management, senior to junior staff of the cable industry in Lagos in order to determine the roles of labour turnover in organisational productivity.

\section{Significance of the study}

In course of determining the roles of labour turnover in organisational productivity, the work revealed an explicit insight into the trend of labour turnover in the cable industry thus providing reasons behind decision to stay or leave in relation to the role played by compensation policies, leadership composition and environment, motivational factors as well as human resources management practices emanating from policies of the organisation. Insights were also provided into the factors that made productivity to increase and at the same time decrease.

\section{LITERATURE REVIEW}

One of the characteristics of modern organisation is continued existence of organisation by operating on-going concern whereas employees may not have continued working relationship with organisation i.e it is somewhat natural for employees to leave an organisation after sometime with or without reasons (Akindele, 1999). The process of leaving and replacing employees over a specified period of time usually a year or more than a year is known as labour turnover (Akindele, 2007). In the views of Flippo (1980) this can be described as the movement into and out of an organisation by the workforce and to him this movement is an index of stability of that workforce. Obisi, (1996) regarded labour turnover as the coming in and going out of employees over a measured period say in a month or a year. He went further to say that if some employees leave an organisation and some people joined the organisation to fill the position vacated then labour turnover has taken place and could be as a result of many reasons, incidents and factors. Graham was of the opinion that labour turnover is the movement of people into and out of the firm. To him it is usually convenient to measure it by recording movement out of the firm on the assumption that a new employee eventually replaces a leaver for any reason. However, the views of Adebayo, Ajayi \& Oginni (2013) was different to what the above scholars adduced forward to describe what labour turnover is all about. In their views, labour turnover is strictly movement out of an organisation with the intention to join or not join another organisation. The argument was based on the fact in the developing economy like Nigeria it is not always a direct relationship i.e replacing every employee that left the organisation more so that the economic situation put pressure of the organisation to utilise resources to the maximum. When an employee leaves, what follow is adjustment to merge the vacuum created except a sensitive position which is taking over by next in hierarchy pending the appointment of another to fill the vacancy.

The rate of turnover varies from organisation to organisation as well as region to region and the highest number of turnover recorded in Nigeria is the private sectors unlike the public sector which enjoys relative stability (Oginni, 2011) and the reasons behind this labour turnover were many out which few were mentioned availability of alternative employment was identified by Ubeku, (1975) which also corroborated the views of Hyman (1970) that the existence of job opportunities within the economy acts as a pull factor in workers' decision to 
change jobs. Flippo (1980) identified errors made in the placement and orientation to be another source of causes which was also supported by Akinnusi (1989) and added mismatch of personnel to jobs. Fajana (2011) linked God Fatherism to the problem arising from improper placement of mismatch of personnel to jobs which end result is frustration causing on timely departure from the organisation. To Obisi (1996) unhappiness, relationship with management and work environment evolving from the job and individual interaction were another sources of labour turnover. This view was supported by Cameron (1994) and added managerial inefficiency leading to frustrating and demoralising for dedicated employees to sit around waiting for work while management engages in interplay of work activities. Also, variables such as the state of the economy, the nature and characteristics of the job, wage structure, demographic characteristics of individual in the environment unrealistic expectation, poor candidate screening, compensation issues job-scope, work tools and job security were identified as potential causes of labour turnover (Williams etal, 1994, Jackson, 1981 and Stear, 1991). These identified causes according to Banjoko (2000) can be classified into two namely pull and push factor and Ruby (2002) added another dimension to it by adding internal and external. The pull factors are those variables that are outside the organisation attracting employees to leave their present jobs while the push factors are the variables within the organisation propelling employees to leave their job. Fajana (2011) classified it into two as voluntary and involuntary.

It is logical to say that labour turnover can be extremely devastating for any organisation as a result of their inability to maintain stead and balance workforce. However, the cost associated with labour is enormous ranging from loss of goodwill, leakage of information to competitors by departing employees, loss of investment on the departing employees in terms of training, disruption in work process and plan, cost incur in recruitment exercises, diminishing organisational effectiveness, loss of job-specific skills, conflicting organisational culture and to increase in scraps (Stear, 1991, Ovadge, 1998, Testa, 2008, Ubeku, 1975, Chruden, 1980, Mobley, 1982, Shaw etal, 2001, Fajana, 2011). In the same vein, it also has effect on employees such as loss of wages, loss of societal respect and prestige, suffers career advancement and emotional trauma (Armstrong, 1993). Although the effect is devastating, it is also beneficial in some ways such as injection of fresh blood with new ideas, room to ensure and facilitate promotion, training need arises for members of the organisation and get rid of unproductive employees (Abelson, 1987). The above effect clearly depict the views of Obisi (1996) when he said that there is gain in movement of employees out of the organisation as no organisation can exist without iota of labour turnover but such movement should be watched and monitored. This was equally illustrated by the work of Graudet (1958) on what top management does not know about turnover in Banjoko (2000) through the use of Fahrenheit measurement as a clinical thermometer to draw his analogy i.e a high temperature may mean pneumonia, measles or mumps and also a below normal reading on the thermometer can also be a danger signal. Bolton (1991) provided a simple method by which this can be measured or calculated i.e labour turnover is equal to the number of employees leaving divided by the average total number of employees multiplied by 100 since it is usually expressed in percentage and the number of employees leaving are measured over one calendar year.

\section{Productivity}

In the views of Maertz etal (1998) productivity is the measure of an organisation to achieve its targeted production with the means of workforce, authority's strategies, machineries, equipments and assets. To Harper (1982) productivity is a measure of output from production process, per unit of output. In a nutshell, it is a ratio to measure how well an organisation converts input resources into goods and services (Saari, 2006). Mayabeo and karmarkar (1962) in Obisi (2005) productivity is described as the ratio between the production of a given 
commodity measured by volume and one and more of the corresponding input factors which measured by volume. However, the views of Benson, (2002) differ as result of his perspective on what productivity is all about. He believed that productivity means an organised mass attack on waste of every type and in every sphere. Benson (2002) went further that it implies development of an attitude of mind and a constant urge to find better, cheaper, quicker, easier and safer ways of doing a job, manufacturing an article and providing service. A deeper examination of these showed that the process of productivity imbibed the concept of effectiveness and efficiency, labour (skilled and unskilled), raw materials and other factors of production. Therefore, productivity is getting it right the first time by ensuring effectiveness and efficiency in process, man and material.

This just explains why many scholars were of the opinion that productivity depends on several factors such as motivation, talent, training, work environment, support from others, time management, luck, land, competent workforce, leadership, political stability, reward strategies, social stability, security, law and legislation, supervision, environmental factors, international factors, technology factors, planning and communication (Obisi, 2005, Adamu, 2015). However, in the opinion of the authors, all these factors can be classified into three categories namely personal factors, work factors and environmental factors. It is these factors that made productivity to be a deliberate effort to build integrity, value and transparency in an organisational culture in order to create enabling environment for the workforce that would induce productivity in organisation and where these factors are positive, to maintain stability in the workforce of any organisation will not be difficult (Penrose, 1980).

\section{Challenges of Labour turnover and productivity}

Out of all the factors mentioned above, it is the "man" that receives greater attention as the chief component of the variables affecting productivity. This is because man is the most dynamic and unpredictable element thus making it difficult for adequate planning of this resource when compared with other variables that were relatively static in nature except with man interaction. Similar to this is the head haunting or poaching of qualified and competent employees as the case may be on the part of the competitors. This is a deliberate attempt on the part of the competitors to lure qualified and competent employees away from their present place of work with mouth watering compensation package and since employees are economic human being there is always that temptation to leave their present job and join the new one (Obisi, 2005, Chruden (1980) and Fajana, 2011). The departure of an employee from an organisation would create vacuum in the job process and thus affect time taken to complete the work and when eventually replaced, the time it will take to acclimatise to the organisation and its culture, waste in materials and time in decision making, advertisement financial implications due to recurring of replacement of the departed employees. Another major challenge is poor compensation package that is being described in Nigeria as total take home which upon critical examination, it cannot take one to the gate of the organisation talk less of the home and the implication is unwarranted movement on the part of the employees seeking a better compensation package by vividly relying on the information provided either by friends, associates or grapevine discussions (Adamu, 2015). Organisations are equally handicapped to offer attractive compensation package as a result of economic recession presently prevailing in Nigeria thus compounded the stability of workforce and steady productivity devoid of unwarranted (Obisi, 1996). An aggrieved departing staff can put employer at bad light and lure other employees out of the organisation. This additional turnover caused by departing staff can result to difficulty in employing good employee and thus hampering the productivity of such organisation (Benedict, 2012). 


\section{METHODOLOGY}

The paper relied on both primary and secondary data. Primary data were collected through a structured questionnaire which was administered personally in a face to face situation to the employees of the cable industry in the manufacturing sector of Nigerian economy by the researchers in the three senatorial districts that constitutes Lagos, Nigeria where each of the researchers covered a district. The population of study consists of 5 cable organisations obtained through a preliminary survey of the cable manufacturing organisations in the three senatorial districts of Lagos state namely Lagos West, Lagos Central and Lagos East which was based on the number of years of existence with 650 employees and from the employees' number in the organisations based on the preliminary survey, a sample of 420 employees were chosen representing 65\% (140 from each of the senatorial district) which was randomly selected from purposively chosen manufacturing organisation in the senatorial districts of Lagos.

A total of 420 questionnaires were administered to the employees in the cable organisations of the three senatorial districts in Lagos over a period of 7 months which was developed in line with Likert five rating points which consists of different questions on personal factors, work factors and environmental factors in order to determine the relationship between labour turnover and productivity. The respondents were asked to express their opinion to each of the dimensions of labour turnover with appropriate score that commensurate with their level of agreement where strongly agree $=5$, agree $=4$, neutral $=3$, disagree $=2$ and strongly disagree $=1$. The items for measuring labour turnover have been developed based on Schwepker and Charles (2001) as well as Heinonen and Korvela (2003) studies and for reliability purpose Cronbach Alpha was used and the reliability value was 0.925 which was equal to 1 as obtained through the use of SPSS analysis. In all, 397 were returned while 356 questionnaires were found to be adequate for the purpose of analysis thus representing 85\% respondents' rate and the secondary data used in the study was obtained from related journals, books, internet etc. and descriptive and inferential statistics were used to examine organizational productivity 


\section{ANALYSIS AND INTERPRETATION}

Table 1: Demographic Information about the respondents

\begin{tabular}{|c|c|c|}
\hline Variables & Frequency distribution & Percentage \\
\hline Gender & & \\
\hline - Male & 215 & $60 \%$ \\
\hline - Female & 141 & $40 \%$ \\
\hline - Total & 356 & $100 \%$ \\
\hline Marital status & & \\
\hline - Single & 115 & $32 \%$ \\
\hline - $\quad$ Married & 235 & $66 \%$ \\
\hline - Divorced & 6 & $2 \%$ \\
\hline - Widow & - & - \\
\hline - Widower & - & - \\
\hline - Total & 356 & $100 \%$ \\
\hline Educational level & & \\
\hline - M.Sc / MBA & 37 & $10 \%$ \\
\hline - $\quad$ B.Sc/HND & 189 & $53 \%$ \\
\hline - ND/NCE & 89 & $25 \%$ \\
\hline - Others & 41 & $12 \%$ \\
\hline - Total & 356 & $100 \%$ \\
\hline Work experience & & \\
\hline - Less than 1 year & 22 & $6 \%$ \\
\hline - $1-3$ yrs & 88 & $25 \%$ \\
\hline - 4-6 yrs & 178 & $50 \%$ \\
\hline - 6 yrs and above & 68 & $19 \%$ \\
\hline - Total & 356 & $100 \%$ \\
\hline Age limit & & \\
\hline - Less than 30 years & 60 & $17 \%$ \\
\hline - $\quad 31-40$ years & 145 & $41 \%$ \\
\hline - $41-50$ years & 109 & $31 \%$ \\
\hline - $\quad 51$ and above years & 42 & $12 \%$ \\
\hline - Total & 356 & $100 \%$ \\
\hline
\end{tabular}

Source: Field Study, 2018

Table 1 above showed the demographic characteristics of the respondents which was sought in order to determine the suitability of the respondents in terms of maturity, emotional stability, knowledge and experience for reliability on the outcome of the research work. The table showed that in the gender category, male with 215 respondents representing $60 \%$ of the population were the majority. In the same vein of the majority were married respondents with 235 representing $66 \%$ of the population, first degree holders with 189 representing $53 \%$ of the population, 178 respondents representing 50\% were also the majority with respect to the number of years spent in their present organisation and in the age limit category, 145 respondents representing 41\% were within the age bracket of 31-40 years to be the majority. Overall, the implication is that the respondents are matured, educated, qualified to understand what the questions in the questionnaire were all about and could be deduced that the respondents are emotionally stable going by the ratio of divorce and married respondents. The percentage recorded for age and work experience showed that the respondents can adequate comment on the issue at stake with reference to their daily activities and knowledge about their respective organisation. 
Table 2: Percentage of labour turnover and organizational productivity

\begin{tabular}{|l|c|c|c|c|}
\hline & PF & WF & EF & OF \\
\hline Strongly agreed & 43.3 & 51.1 & 23.2 & 24.7 \\
\hline Agreed & 23.2 & 15.2 & 45.5 & 17.3 \\
\hline Neutral & 6.1 & 18.4 & 12.3 & 18.6 \\
\hline Disagreed & 16.4 & 9.5 & 10.4 & 21.1 \\
\hline Strongly disagreed & 11 & 5.8 & 8.6 & 18.3 \\
\hline TOTAL & 100 & 100 & 100 & 100 \\
\hline
\end{tabular}

Source: Field Study, 2018. Where PF = Personal factors, WF = Work factors, EF = Environmental factors and $\mathrm{OF}=$ Organisational policies factors

Table 2 showed the percentage of employees' responses as well as perspective on different dimensions of labour turnover and organizational productivity. Emerging from the above table 2 is that majority of the respondents representing $51.1 \%$ strongly believe in their opinion that work factors has effect on the productivity of an organisation, $15.2 \%$ of the respondents were also in support of work factors as a phenomenon that affect organisational productivity, in all $66.3 \%$ agreed that work factors has effect on productivity of an organisation while $15.3 \%$ total number of respondents were against the belief that work factors has effect on organisational productivity, thus implying that management of the cable industry should endeavour to make work interesting through appropriate work design in order to avoid losing competent employees so that the effect of it on the organisational productivity would be minimal. Followed by the respondents with $43.3 \%$ who strongly agreed that personal factors also has effect on the productivity of an organisation and $23.2 \%$ agreed to the belief that personal factors has effect on organisational productivity, in all $66.5 \%$ believed that personal factors has effect on the productivity of an organisation. A comparison between work factors and personal factors in terms of respondents' percentages showed that those that were in support of personal factors were more than those in support of work factors by $0.2 \%$ and those that in disagreement about the effect of the variables on productivity were equally not on the same plane i.e $17.5 \%$ of the respondents were against work factors while $15.3 \%$ of the respondents were against personal factors to have effect on the productivity of the organisation thus creating a margin of $2.3 \%$. A total number of $68.7 \%$ respondents agreed that environmental factors has effect on organisational productivity while 19\% respondents were in disagreement with the effect of environmental factors on organisational productivity and this particular variable provided the highest number of respondents. The implication is that the management of cable industry should incorporate basic environmental factors into the organic functioning of the organisation. Similarly, $42 \%$ respondents were also in agreement with organisational policies as a factor to have effect on the productivity of the organisation while $49.4 \%$ respondents representing the highest number to disagree with organisational policies. The implication of this is that most of these respondents were not attributing their decision to leave their present place of work to policies emanating from the organisation rather place their focus on the happenings in the environment, individual perception in relation to balance work life and the work itself in terms of operation and performance.

Table 3: Computation of $Z$ value at 0.05 level of sig. (two tailed test); table value (1.96)

\begin{tabular}{|l|l|l|l|l|l|l|}
\hline $\begin{array}{c}\text { Organizational } \\
\text { Productivity }\end{array}$ & $\mathrm{N}$ & Mean & $\begin{array}{c}\text { Standard } \\
\text { Deviation }\end{array}$ & $\begin{array}{c}\text { Standard } \\
\text { error }\end{array}$ & $\begin{array}{c}\text { Z Value } \\
\text { (calculated valued) }\end{array}$ & $\begin{array}{c}\text { Mean } \\
\text { Rank }\end{array}$ \\
\hline Personal factors & 356 & 55.4 & 14.3 & 0.12 & 1.43 & 1 \\
\hline $\begin{array}{l}\text { Environmental } \\
\text { factors }\end{array}$ & 356 & 45.2 & 12.7 & 0.13 & 1.64 & 2 \\
\hline Work factors & 356 & 38.6 & 10.8 & 0.12 & 1.08 & 3 \\
\hline $\begin{array}{l}\text { Organisational } \\
\text { policies factors }\end{array}$ & 356 & 42.4 & 14.2 & 0.11 & 2.47 & 4 \\
\hline
\end{tabular}

Source: Field Study, 2018 
Table 3 showed that personal factors has calculated value $(Z=1.43)$ and the table value (1.96) which means the tabulated is greater than the calculated i.e. (Ztal > Zcal). This implies that personal factors would have significant effect in the productivity of an organization. Environmental factors calculated value $(Z=1.64)$ and the table value $(1.96)$ indicates that the calculated is less than the tabulated i.e. (Zcal $<$ Ztal). The implication is that environmental factors would really have significant effect on employees' decision to leave their present organisation and thus affecting the productivity of an organisation. With respect to work factors, the calculated value $(\mathrm{Z}=1.08)$ and the table value (1.96) thus, the tabulated is greater than the calculated i.e (Ztal > Zcal) therefore work factors has significant effect on employees' decision to leave their present organisation and thus affecting productivity of an organisation. For organisational policies factors, calculated value (2.47) and the table value (1.96) which means that the calculated value is greater than tabulated value i.e (Zcal $>$ Ztal). The implication is that organisational policies as a factor have insignificant effect on employees' decision to leave their present organisation and thus have minimal effect on the organizational productivity level.

\section{DISCUSSION OF FINDINGS}

The demographic characteristics of the respondents showed that the respondents were found to be matured, emotionally stable, knowledgeable and experienced thus establishing the reliability of the respondents' responses as well as the outcome of the research work. Aside this, the percentage analysis of the variables indicated that environmental factors accounted for more in labour turnover than other variables i.e it is the incident in the vicinity and surroundings of business organisation that would contribute more to the intention of employees to quit their present place of work. The incident may be one or combination of these items namely economic issues, cultural issues, pace of technology, direction of government policies, attitude of the competitors, behaviours of community where the business is sited, availability of alternative job, influence of suppliers and stakeholders. All these are propeller to persuade employees to leave and when it happens, the productivity level of an organisation will surely be affected. This outcome is in support of the related work carried out by Adamu, (2015) on the relationship between technology and organisational productivity where emphasis was on the dictate of the environment vis-a-vis technology as found in operation either within or outside the organisation and was also supported by the work of Obisi, (2005) on related work. Another variable that was also found to have relationship with labour turnover was personal factors. The implication of this for the research work is that after environmental factors, it is followed by personal factors which will equally have bearing on the propensity of employees to stay or not to stay with appropriate consequences on the productivity level of an organisation be it service or manufacturing organisations. It may be one or combination of the items in personal factors that might initiate the decision to quit which includes age, experience, relationship, emotional feelings, perception, individual differences, qualifications, integrity, recognition, spouses, family background, children, distance and parental influence. Whenever any of these manifest, the end result might be labour turnover which will definitely affect the productivity of the organisation in no small measure. This outcome was equally supported by the work of Fajana (2002) and that of Chruden (1980). The other factor considered for the research was work factors as propeller of labour turnover which will also have bearing on the productivity level of the organisation. It may be one or combination of the elements in work factors that might initiate the decision to quit which has career path, growth, advancement, promotion, job design (enlargement and enrichment), work arrangement, time schedule for resumption and operation as well as activities in a task. This particular result can be said to be a confirmation of the work of Herzberg on motivation to be relevance to African settings The last variable in the percentage analysis was organisational policies factors which is deeply rooted in the human resources 
management practices of an organisation which shows that the state of the economy, non availability of alternative job as well as the survival instincts placed restriction on the organisational policies factors as a vital force that could make employees to contingent their decision to leave thus minimising its effect in the productivity level. This contradicted the views of Kersley etal (1997) that policies in organisation have bearing in productivity growth most especially the manners and styles by which it was communicated to the employees. The reason for the contradiction may be as result of variation in continent and country as Nigeria is developing country.

The result emanating from the Computation of $\mathrm{Z}$ value at 0.05 level of sig. (two tailed test) in table 3 on all the dimensions of labour turnover and productivity also confirmed the result obtained from percentage analysis in table 2 . It was evident that personal factors, work factors and environmental factors have significant effects on organisational productivity while organisational policies factors have insignificant effect on organisational productivity which may be as a result of peculiarity of Nigerian situation especially the economic situation.

\section{CONCLUSION}

The main essence of the research work was to determine the relationship between labour turnover and organisational productivity in the manufacturing sector of Nigerian economy most especially the cable industries. The overall analysis provided a comprehensive description for all the variables in the labour turnover and organisational productivity as well as the views of other scholars that had conducted research earlier in related areas. The results obtained through the use of the research instrument were within the stream line as mentioned by previous scholars thus, revealing that work factors, environmental factors, personal factors as well as organisational policies factors are the basic components of labour turnover with certain degree level of influence on the organisational productivity. It was found that most of the employees agreed that work factors, environmental factors and personal factors significantly affected organisational productivity. It was however found that the policies made available in the cable industries did not propel the present crop of employees in the industries to indicate willingness to leave which implies that the policies will bring about stability in the work force and the effect on the productivity can be said to be minimal. This was inferred from the fact that an employee willing to leave will give notice as specified in the appointment letter and the period could be used to ensure stability.

Therefore, labour turnover is an indicator of organisational productivity level as a result of the existing relationship between the two variables. To this extent, labour turnover is a variable that must be considered in order to maintain and guarantee stability in the organisational productivity level otherwise these organisations will begin to lose their productivity on daily basis as well as serving as a profit leaking source and may eventually lead to untimely wind-up of the organisation in the long run. However, the outcome of the research is not limited to the cable industry but can serve as basis for proactive action for other business organisations that has profit as their primary objective.

\section{RECOMMENDATIONS}

Sequel to the conclusion in the study, the following recommendations are suggested as a way to minimise the degree of employees' movement in order to reduce labour turnover as well as obtaining stability in the productivity of the organisation;

1. That the management of the organisation should device a means to monitor employees' performance over identifiable measurement of criteria in order to discover any kind of dwindling in performance which might be due to some personal factors before it is escalated and becomes a problem thus nipping it in the bud. 
2. That the management of the organisation should endeavour to design work and structure that ensures effective accomplishment of set objectives and also that would not see man as machine but as having feelings, attitude and needs to meet. The design of work with appropriate structure will assist employees in the discharge of their duties.

3. That the management of the organisation should provide a suggestion box placed in a conspicuous place with assurance that the information provided shall surely be used for the purpose of improving organisational efficiency and that information provided should be under anonymity.

4. That the management of the organisation should from time to time conduct environmental scanning in the environment within the reach of the business organisation in order to understand activities as well as developments in the environment with a view of responding to these activities and the developments.

5. That the management of the organisation should also ensure that recruitment process is fair and free from unwarranted influences so that appropriate placement could be carried out that would not make the existing employees to nurse any feelings of disaffection towards the end result of the process.

6. That the management of the organisation should endeavour to make the human resources management practices to be robust in order to accommodate contingency issues and situations in order to withstand test of time by being relevant from time to time.

\section{References}

Adamu, K. B (2015): Understanding Human Resources Management for Practices, Muson Publishing House, Lagos, Abelson, M.A (1987): Examination of Avoidable and Unavoidable Turnover, Journal of Applied Psychology,24, pp 382 - 386

Adebayo, I.O, Oginni, B.O and Ajayi, N.O (2013): Management: A practical approach, Kay Publishing Ltd, Somolu Lagos.

Armstrong Michael (2004): A Handbook of Human Resource Management, Practice, $8^{\text {th }}$ ed. Koga Page Ltd, London.

Armstrong, M (1993): Survivors' reactions to a workforce reduction: A comparison of blue collar workers and their supervisors, Canadian Journal of Administrative Sciences, 10(4), pp 334 - 343.

Akindele, R.I (1999): How to Motivate Nigerian Workers, A case study of Nigerian Bottling Company, the Quarterly Journal of Administration, Obafemi Awolowo University, Ile-Ife vol. 30 pp 337 -344.

Akindele, R.I (2007): Fundamental of Human Resources, Cedar Publishing Productions, Ile -Ife, Osun State.

Akinwusi, D.M (1989): Towards Improving Business Performance Through Effective Human Resources Management $2^{\text {nd }}$ Biennial conference, Faculty of Business Administration, University of Lagos, pp 4

Banjoko A. Simbo (2000): Human Resources Management: An Expository approach, Saban Publishers, Lagos.

Benedict, A.C, Josiah, M and Akpeti, E (2012): The effect of Labour turnover in Breweries Industries in Nigeria; A case study of Guinness Brewery Industries Plc and Bendel Brewery Ltd in Benin city, Asian Journal of Business Management, vol. 4, (2), $114-123$

Bolton, T. (1991): Human Resource Management: An Introduction. Blackwell Publishers, London, pp: 17-19.

Brockner, J. (1992): Managing the effects of Layoff on others, California Management Review, pp 9 - 27.

Cameron, K.S (1994): Investigating organisational downsizing-fundamental issues: Human Resources Management Journal, 32(2), pp $183-188$

Chruden, S (1980) Personnel Management: The Utilization of Human Resources Florida South West Press, U.S.A, pp: 54 .

Kersley, B. and C. Martin, (1997): Productive growth, Participation and Communication. Scottish Journal of Political Economy, vol. 44, pp 485-501.

Fajana (2011): Human Resource Management, An introduction, Labofin and company, Lagos. 
Flippo Edwin (1990): Personnel Management, Japan, McGraw-Hill Book Company

Graham, H.T (1989): Human Resources Management, M \& E Handbooks on Business and Management, $6^{\text {th }}$ ed. Pitman Publishing, London.

Gaudet, F.J (1958): What Top Management does not know about Turnover, Personnel Administration, New York, vol. 34(5)

Harper, W.M (1982): Cost and Management Accounting, $2^{\text {nd }}$ ed. Macdonald and Evans Ltd, Estover-Plymouth.

Heinonen, J and Korvela, K (2003): How About Measuring Intrapreneurship? EISB Conference, Milan

Schwepker, Jr and Charles, H (2001): Ethical Climate's Relationship to Job Satisfaction, Organisational

Commitment and Turnover Intention in the Sales force, Journal of Business Research, 54, 39-52

Jackson, M. (1981): Personnel. $2^{\text {nd }}$ ed, Heinemann Publishers, London.

Mobley, W.H (1982): Employee Turnover, Causes, Consequences and Control, Addison - Wesley Reading.

Maertz, C.P and Campion, M.A (1998): 25 years of voluntary turnover research: A review and critique in C.L Cooper \& I.T Robinson, International Review of Industrial and Organisational Psychology, London, John Wiley \& Sons, Ltd pp 49-86

Obisi (1996): Personnel Management, Jackboot enterprises, Ojokodo layout, Agbowo - Ibadan.

Obisi (2005): Substance of Employee, Industrial and Labour Relations, Megavons (West Africa) Limited, OnipanuLagos.

Oginni, B.O (2011): A study of employee retention strategies and Organisational survival in Private Universities in Southwestern, Nigeria (unpublished M.phil research thesis)

Ovadge, F. (1988): Motivation: Getting people to do their best. Lagos Business School of Management Review, January and June, 1: 3-7.

Penrose, E (1980): The theory of the growth of the firm, $2^{\text {nd }}$ ed. Basil Black well Publisher, Oxford.

Ruby, A.M., (2002): Internal teacher turnover in urban middle school reform. Journal of Education; Students Place at Risk, 7(4): 379-406.

Saari, S. (2006): Productivity Theory and Measurement in Business, Productivity Handbook, Finland. MIDO OY.

Saari, S. (2006): Productivity Theory and Measurement in Business, European Productivity Conference, 30 August-1 September, Espoo, Finland.

Shaw, J., Delery, J., Jenkins, G., and Gupta, N (2001): An Organisation-level Analysis of Voluntary and Involuntary Turnover, Business School Research Series

Stear, R.M (1991): Motivation and Work Behaviour. McGraw Hill, U.S.A., pp: 168-266.

Testa, B (2008): Early engagement, long relationships? Workforce Management, 15: 27-31.

Ubeku, A.K (1975): Personnel Management in Nigeria, Ethiope Publishing Company, Benin City, pp: 5-7.

Williams, Charles R and Linda Parrack Livingstone (1994): Another look at the relationship between performance and voluntary turnover, Academy of Management Journal, 37(2), 269 - 298. 